\title{
Sexual dimorphism in shell morphology of mollusks of the genus Viviparus - important objects of water resources of Ukraine
}

\author{
Olena Uvayeva ${ }^{1}$, Tetiana Vakaliuk $^{2,}$, Georgiy Shcherbina $^{3}$, and Elena Shimkovich ${ }^{4}$ \\ ${ }^{1}$ Zhytomyr Polytechnic State University, Faculty of Mining and Ecology, 10005 Zhytomyr 103, Chudnivska Str., Ukraine \\ ${ }^{2}$ Zhytomyr Polytechnic State University, Faculty of Information and Computer Technology, 10005 Zhytomyr 103, Chudnivska Str., \\ Ukraine \\ ${ }^{3}$ Papanin Institute for Biology of Inland Waters, Russian Academy of Sciences, 152742 Borok, Nekouz, Yaroslavl, Russian Federation \\ ${ }^{4}$ Kazan Federal University, Preparatory School for International, 420008, Kazan 18, Kremlevskaya Str., Russian Federation
}

\begin{abstract}
Bioindication assessment of water bodies of Ukraine can be carried out using the ratio of males and females of mollusks of the genus Viviparus. In practice, it is very convenient to determine the sex of mollusks by the differences in their shell. Male and female freshwater snails Viviparus viviparus (Linnaeus, 1758) and $V$. contectus (Millet, 1813) are shown to have reliable differences in shell morphology depending on their age. There is almost no sexual dimorphism by shell morphometrics and indices in Viviparus snails aged one to three years. After three years of life, mature females have significantly larger shell width, higher body whorl, and size of the aperture. Females of $V$. viviparus at the age of two to five years may be differentiated from males by the relationship of mean shell width and shell height, which is statistically significant higher than in males. This difference is explained by the different size of the mantle section genital organs of mature male and female. The obtained results should be taken into consideration in establishing the sex of viviparid snails.
\end{abstract}

\section{Introduction}

Mollusks of the genus Viviparus Montfort, 1810, namely $V$. viviparus (Linnaeus, 1758) and $V$. contectus (Millet, 1813) are quite common in the rivers, floodplain lakes and large ponds of Ukraine, in which they can accumulate significant numbers and biomass [1]. The freshwater pond snails are essential in the maintenance of water ecosystems, as part of various trophic chains, particularly as intermediate hosts of many bird parasites [2]. Also, these prosobranch gastropods with filtration and sedimentation cleanse water bodies from suspended matter, depositing it on the bottom [3, 4].

Viviparid snails were found useful for bioindication of water bodies of Ukraine [5]. For that, the ratio of males to females in the mollusk population is used. The sex structure of freshwater pond snails in water bodies with an increased organic matter content (alphamesosaprobic and polysaprobic zones) is characterized by an increase in the number of females, less often young (1-3-year-olds individuals) males [1]. In practice, it is important to clearly distinguish between male and female freshwater pond snails when conducting bioindication studies.

The representatives of the genus Viviparus are dioecious freshwater snails with exact sexual dimorphism: in males, the right tentacle is shorter, thickened and blunt (transformed into copulatory organ), while in females the right and left tentacles were of the same shape and size. Sex chromosomes in both species were not identified, but there are statistically significant differences in dimensions of homological chromosomes of $V$. viviparus and $V$. contectus males and females [6, 7].

The studies about sexual dimorphism in the shell morphology of Viviparus are contradictory. For example, sexual dimorphism was not found in the shell sizes of $V$. sphaeridius (Bourguignat, 1880) and $V$. viviparus, collected in the Southern Buh river [8,9]. However, statistically significant sex differences in the conchological characters of these species in the Bucha river were noted in that study. Examination of five species of the genus Viviparus ( $V$. viviparus, $V$. contectus, $V$. acerosus (Bourguignat, 1862), V. ater (Christofori et Jan, 1832), and $V$. hellenicus (Clessin, 1879)) revealed no dimorphism between male and female snails in the shell shape [10].

At the same time, a number of studies point out the presence of such differences. In particular, females of Viviparus are usually larger than males, with more convex whorls, and wider aperture [11-13]. T. A. Andriychuk [6] revealed sex differences in the shells of Viviparus using discriminant analysis and dispersion statistical analysis.

Geometric morphometric analyses of three shell characters (ventral/aperture, dorsal, and top/whorl portion) indicated sexual dimorphism in the shape in $V$. angularis (O. F. Müller, 1774) [14]. Sexual dimorphism in the shell sizes was also noted for the

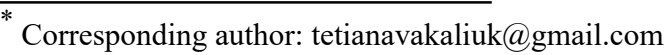


American endemic species $V$. subpurpureus (Say, 1829) [13]. Females of this species have relatively lower shell spire, more convex whorls and larger size of the aperture compared with males. In $V$. viviparus [15] and $V$. contectus [16], there were marked sexual differences by the allometric coefficients of the relationship between shell height, shell diameter (width) and aperture height.

However, there also are reports [such as 17], according to which male snails are larger than females and these differences are statistically significant.

Taking into account the discrepancies in the literature about sexual dimorphism in the shell morphology, we decided to carry out our own study.

The purpose of our work was to study sexual dimorphism in the shell morphology of $V$. viviparus and $V$. contectus, taking into account the age of mollusks.

\section{Material and methods}

The materials for the study were the samples of $V$. viviparus (Fig. 1a) from the Irsha river (city of Khoroshiv, Zhytomyr region, Ukraine; 5060'31" N, $28^{\circ} 45^{\prime} 42^{\prime \prime}$ E) and $V$. contectus (Fig. 1b) from the floodplain of the Tnya river (village of Nesolon,

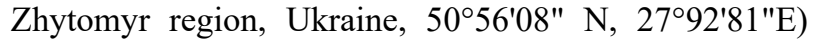
collected in August, 2016. The mollusks were collected at a depth of $1 \mathrm{~m}$. At each station, at least three samples were taken [18].
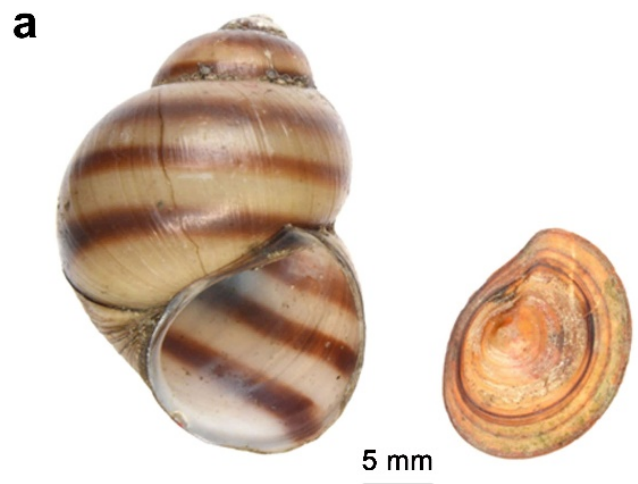

b

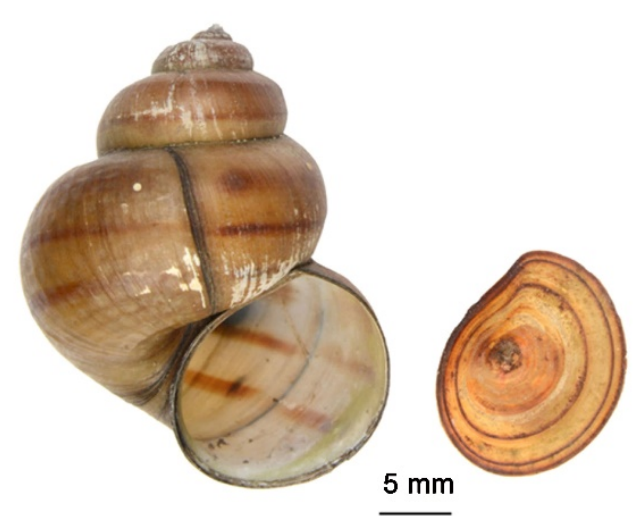

Fig. 1. Shell and operculum of Viviparus viviparus (Linnaeus, 1758) (a) and $V$. contectus (Millet, 1813) (b).

Snail species were identified according to P. Glöer [19] and F.W. Welter-Schules [20].

We studied males and females of viviparid snails with different the shell size and age. The age of the mollusks was determined by the number of concentric dark structure on the operculum, which marks the slower snail growth in winter [1]. The snail sex was determined by the shape of the right tentacle [21].

The shells were measured using a caliper with the accuracy of $0.1 \mathrm{~mm}$. Five shell morphometric parameters were analyzed: shell height $(\mathrm{SH})$, shell width (SW), aperture height $(\mathrm{AH})$, aperture width (AW) and body whorl height (BWH) (Fig. 2) [15]. According to these measurements, the following indices were calculated: $\mathrm{SW} / \mathrm{SH}, \mathrm{BWH} / \mathrm{SH}, \mathrm{AH} / \mathrm{SH}, \mathrm{AW} / \mathrm{SH}$.

The received digital data are processed using standard methods of variation statistics [22]. Descriptive statistics was conducted using the program STATISTICA 6.0. Significant differences between the values were assessed by the Student's $t$-test.

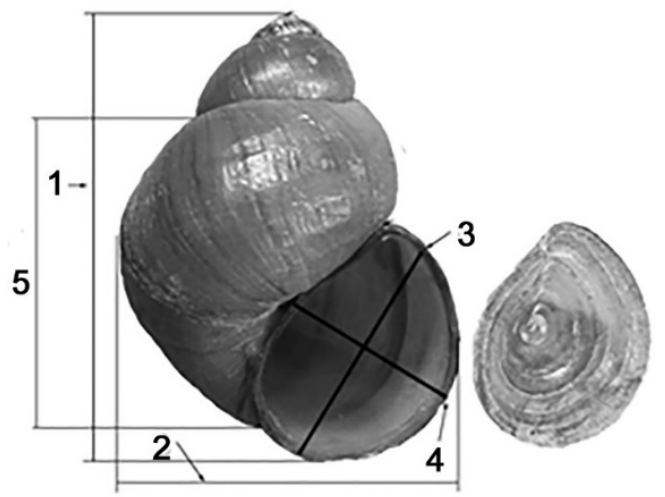

Fig. 2. Measurements on shell morphometric parameters of viviparid snails: 1 - shell height, 2 - shell width, 3 - aperture height, 4 -aperture width, 5 - body whorl height [15].

\section{Results and discussion}

At adverse conditions (prolonged colder winter temperature), the growth of viviparid snails is inhibited. As a result, the ion exchange and sedimentation of $\mathrm{CaCO} 3$ decrease or even completely cease, which leads to the formation of a clear dark concentric structure on the operculum and spiral bands on the shell that are more visible than other formations of different origin.

The river snails under a year in age $(0+$ age $)$ do not have specific sculpture elements on their shells and dark structure on the opercula, because they have not experienced a winter period of slowed growth (Figs. 3, 4). At the same time, the operculum of shell of all age classes, including the one-year-old snails, bear the so-called embryonic mark (Figs. 3e, 4e). It is more or less pigmented and formed during the embryonic development in the body of parent female in winter.

Snails with one spiral band on their shells and oneyear-old concentric structure on the operculum are here designated as 1+; accordingly, 2-6-year-olds are designated as $2+, 3+, 4+, 5+$ and $6+$. Figures 3 and 4 depict the operculum of the $V$. viviparus snails (age from $0+$ to 5 years) and $V$. contectus (age from $0+$ to 6 years) from different populations to visualize their variations in pigmentation, clarity and thickness of annual concentric structure. 


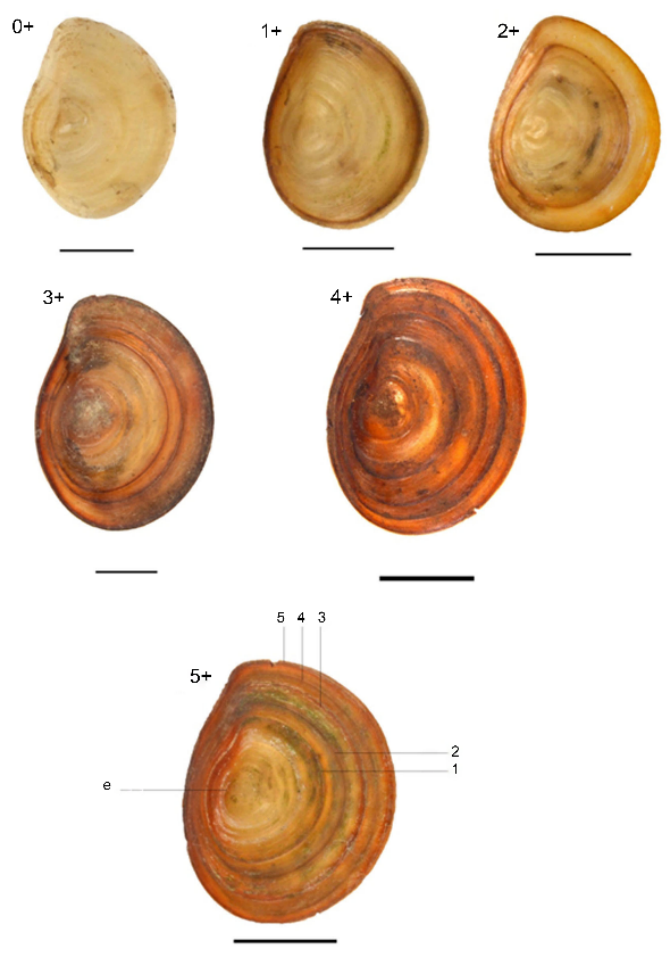

Fig. 3. Winter marks on the operculum of $V$. viviparus: $0+, 1+$, $2+, 3+, 4+, 5+-$ the $1,2,3,4$ and 5 year old specimens, respectively; $1-5$ - post-embryonic marks; e-embryonic mark. Scale is $5 \mathrm{~mm}$.
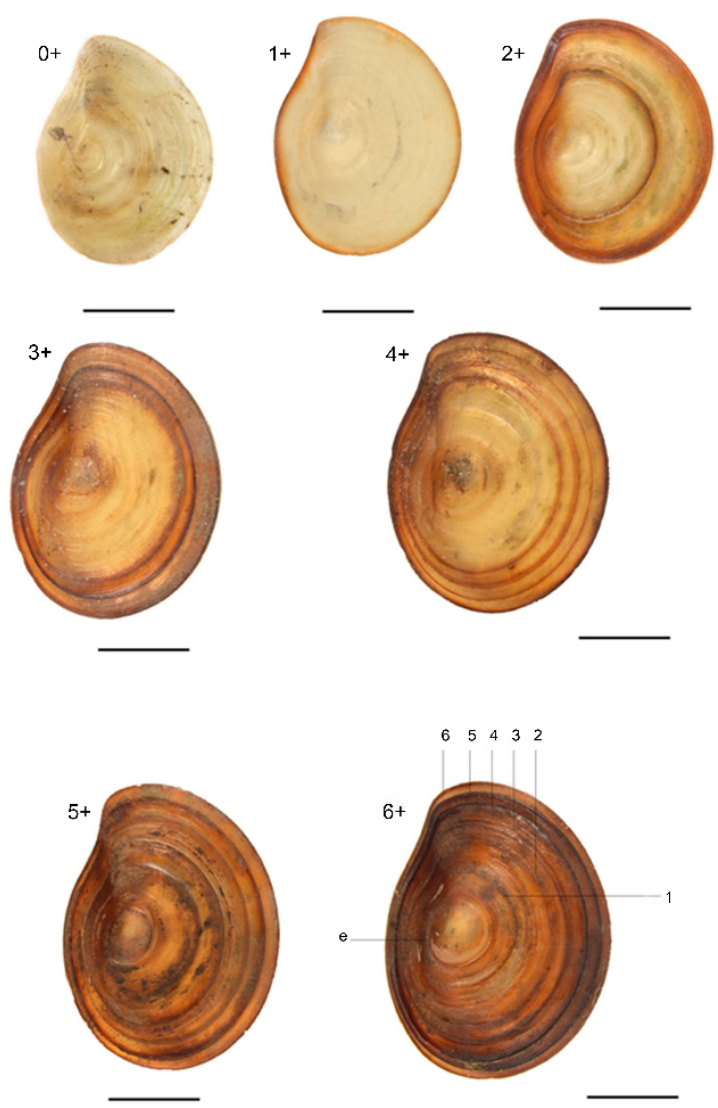

Fig. 4. Winter marks on the operculum of $V$. contectus: $0+, 1+$, $2+, 3+, 4+, 5+, 6+-$ the $1,2,3,4,5$ and 6 year old specimens, respectively; 1-6 - post-embryonic marks; e - embryonic mark. Scale is $5 \mathrm{~mm}$.
In the water bodies of Ukraine, the maximum age of $V$. viviparus mollusks was 5 years and that of $V$. contectus snails was 6 years [1].

We analyzed the representative samples of $V$. viviparus males and females of each age class from one population (Irsha river). When comparing the average values of the shell height, it was found that young (0-2year-olds individuals) have no sex differences in this parameter, at the age of 3 , the males were larger than females, and at the age of 4-5 years, the females were larger than males $(p>0.05)$ (Table 1).

Table 1. Sex differences in shell morphometrics and indices $\left(x \pm m_{x}\right)$ of $V$. viviparus of different age collected in August, 2016 in the Irsha river (city of Khoroshiv, Zhytomyr region).

\begin{tabular}{|c|c|c|c|c|c|c|}
\hline \multirow{2}{*}{$\begin{array}{l}\text { Age } \\
\text { class, } \\
\text { years }\end{array}$} & \multirow[b]{2}{*}{$n$} & \multicolumn{5}{|c|}{ Shell morphometrics ${ }^{1}, \mathrm{~mm}$} \\
\hline & & SH & $S \boldsymbol{W}$ & $B W H$ & $\boldsymbol{A H}$ & $\boldsymbol{A W}$ \\
\hline \multirow{2}{*}{$0+$} & $\underline{20}$ & $14.9 \pm 0.1$ & $10,8 \pm 0,1$ & $\underline{8.7 \pm 0.2}$ & $10.0 \pm 0.1$ & $\underline{8.7 \pm 0.1}$ \\
\hline & 20 & $15.1 \pm 0.1$ & $11,0 \pm 0,1$ & $8.8 \pm 0.1$ & $9.9 \pm 0.2$ & $8.8 \pm 0.1$ \\
\hline \multirow{2}{*}{$1+$} & 20 & $\underline{18.1 \pm 0.1}$ & $14,0 \pm 0,2$ & $\underline{8.9 \pm 0.1}$ & $\underline{11.1 \pm 0.2}$ & $9.1 \pm 0.1$ \\
\hline & $\overline{20}$ & $\overline{18.2 \pm 0.2}$ & $\overline{14,2 \pm 0,3}$ & $\overline{9.0 \pm 0.1}$ & $\overline{11.0 \pm 0.2}$ & $\overline{9.2 \pm 0.1}$ \\
\hline \multirow{2}{*}{$2+$} & $\underline{20}$ & $\underline{20.8 \pm 0.3}$ & $\underline{15,2 \pm 0,1}$ & $9.2 \pm 0.2$ & $\underline{12.1 \pm 0.1}$ & $\underline{10.0 \pm 0.1}$ \\
\hline & 20 & $20.5 \pm 0.2$ & $16,4 \pm 0,2$ & $10.0 \pm 0.1$ & $12.4 \pm 0.1$ & $11.2 \pm 0.1$ \\
\hline \multirow{2}{*}{$3+$} & $\underline{15}$ & $23.0 \pm 0.2$ & $\underline{17,5 \pm 0,1^{*}}$ & $\underline{10.8 \pm 0.2 *}$ & $\underline{12.9 \pm 0.2}$ & $\underline{12.8 \pm 0.3 *}$ \\
\hline & 15 & $22.2 \pm 0.3$ & $19.6 \pm 0.3$ & $11.9 \pm 0.3$ & $13,0 \pm 0,3$ & $13,9 \pm 0,2$ \\
\hline \multirow{2}{*}{$4+$} & $\underline{10}$ & $\underline{25.1 \pm 0.3}$ & $\underline{18.1 \pm 0.2^{*}}$ & $\underline{11.3 \pm 0.2 *}$ & $\underline{13,3 \pm 0,3}$ & $\underline{14,8 \pm 0,2 *}$ \\
\hline & $\overline{10}$ & $\overline{26.5 \pm 0.2}$ & $\overline{20.8 \pm 0.3}$ & $\overline{12.8 \pm 0.2}$ & $\overline{13,8 \pm 0,2}$ & $15,9 \pm 0,3$ \\
\hline \multirow{2}{*}{$5+$} & $\underline{5}$ & $\underline{28.7 \pm 0.2}$ & $\underline{19.2 \pm 0.3 *}$ & $\underline{16.0 \pm 0.2 *}$ & $\underline{14,0 \pm 0,3}$ & $\underline{15,8 \pm 0,2 *}$ \\
\hline & $\overline{5}$ & $30.1 \pm 0.4$ & $22.5 \pm 0.4$ & $17.2 \pm 0,3$ & $14,2 \pm 0,3$ & $17,0 \pm 0,4$ \\
\hline \multirow{2}{*}{$\begin{array}{l}\text { Age } \\
\text { class, } \\
\text { years }\end{array}$} & \multirow[b]{2}{*}{$n$} & \multicolumn{5}{|c|}{ Shell indices } \\
\hline & & $S W / S H$ & $\begin{array}{c}\boldsymbol{B W H} / \\
\boldsymbol{S H}\end{array}$ & $\boldsymbol{A H} / \mathrm{SH}$ & $A W / S H$ & - \\
\hline \multirow{2}{*}{$0+$} & $\underline{20}$ & $\underline{0.72 \pm 0.01}$ & $\underline{0.58 \pm 0.01}$ & $\underline{0.67 \pm 0.02}$ & $\underline{0.58 \pm 0.01}$ & \multirow[t]{2}{*}{ 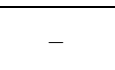 } \\
\hline & 20 & $0.72 \pm 0.01$ & $\overline{0.58 \pm 0.01}$ & $0.66 \pm 0.02$ & $0.58 \pm 0.01$ & \\
\hline \multirow{2}{*}{$1+$} & $\underline{20}$ & $\underline{0.76 \pm 0.01}$ & $\underline{0.49 \pm 0.02}$ & $\underline{0.61 \pm 0.02}$ & $\underline{0.50 \pm 0.01}$ & \multirow[t]{2}{*}{-} \\
\hline & $\overline{20}$ & $\overline{0.78 \pm 0.02}$ & $\overline{0.49 \pm 0.01}$ & $\overline{0.60 \pm 0.01}$ & $0.50 \pm 0.01$ & \\
\hline \multirow{2}{*}{$2+$} & $\underline{20}$ & $\underline{0.75 \pm 0.01 *}$ & $\underline{0.44 \pm 0.02}$ & $\underline{0.58 \pm 0.01}$ & $\underline{0.48 \pm 0.01}$ & \\
\hline & $\overline{20}$ & $\overline{0.81 \pm 0.03}$ & $\overline{0.48 \pm 0.01}$ & $\overline{0.60 \pm 0.02}$ & $\overline{0.54 \pm 0.01}$ & \\
\hline \multirow{2}{*}{$3+$} & $\underline{15}$ & $\underline{0.76 \pm 0.02 *}$ & $\underline{0.46 \pm 0.03^{*}}$ & $\underline{0.56 \pm 0.02}$ & $\underline{0.55 \pm 0.02 *}$ & \\
\hline & 15 & $0,83 \pm 0,02$ & $0,53 \pm 0,01$ & $\overline{0,58 \pm 0,04}$ & $0,62 \pm 0,01$ & \\
\hline \multirow{2}{*}{$4+$} & $\underline{10}$ & $\underline{0,72 \pm 0,03 *}$ & $\underline{0,45 \pm 0,02}$ & $\underline{0,52 \pm 0,04}$ & $\underline{0,58 \pm 0,02}$ & \multirow[b]{2}{*}{-} \\
\hline & 10 & $0,78 \pm 0,02$ & $\overline{0,48 \pm 0,03}$ & $\overline{0,52 \pm 0,03}$ & $0,60 \pm 0,03$ & \\
\hline \multirow{2}{*}{$5+$} & $\underline{5}$ & $\underline{0,66 \pm 0,03 *}$ & $\underline{0,55 \pm 0,02}$ & $\underline{0,48 \pm 0,02}$ & $\underline{0,55 \pm 0,02}$ & \\
\hline & $\overline{5}$ & $0,71 \pm 0,04$ & $0,57 \pm 0,03$ & $0,47 \pm 0,03$ & $0,56 \pm 0,04$ & \\
\hline
\end{tabular}

Notes: 1 - conchological parameters are described in "Material and methods"; the numerator presents the measurements for males, the denominator for females; $n-$ quantity of studied specimens; * - statistically significant difference between sexes $(p<0.05)$.

The average values of the shell width in young individuals ( $0+$ to 1 year old) of both sexes are almost the same. These parameter tend to increase in the females since the age of both when they become mature. At the age of three to five years, this difference is statistically significant $(p=0.05)$.

We analyzed the limits of variability of the shell width for $V$. viviparus males and females of different age (Fig. 5a). The minimum and maximum values of this trait parameter for both sexes often overlapped.

The body whorl height is higher in older females than in males, with statistically significant difference $(p=0.05)$ in 3-5 year old snails. There was no statistically significant difference in the aperture height between sexes of viviparid snails. As for the aperture width, in older (3- 
5-year-olds) females this parameter is significantly $(p=0.05)$ higher than in males.
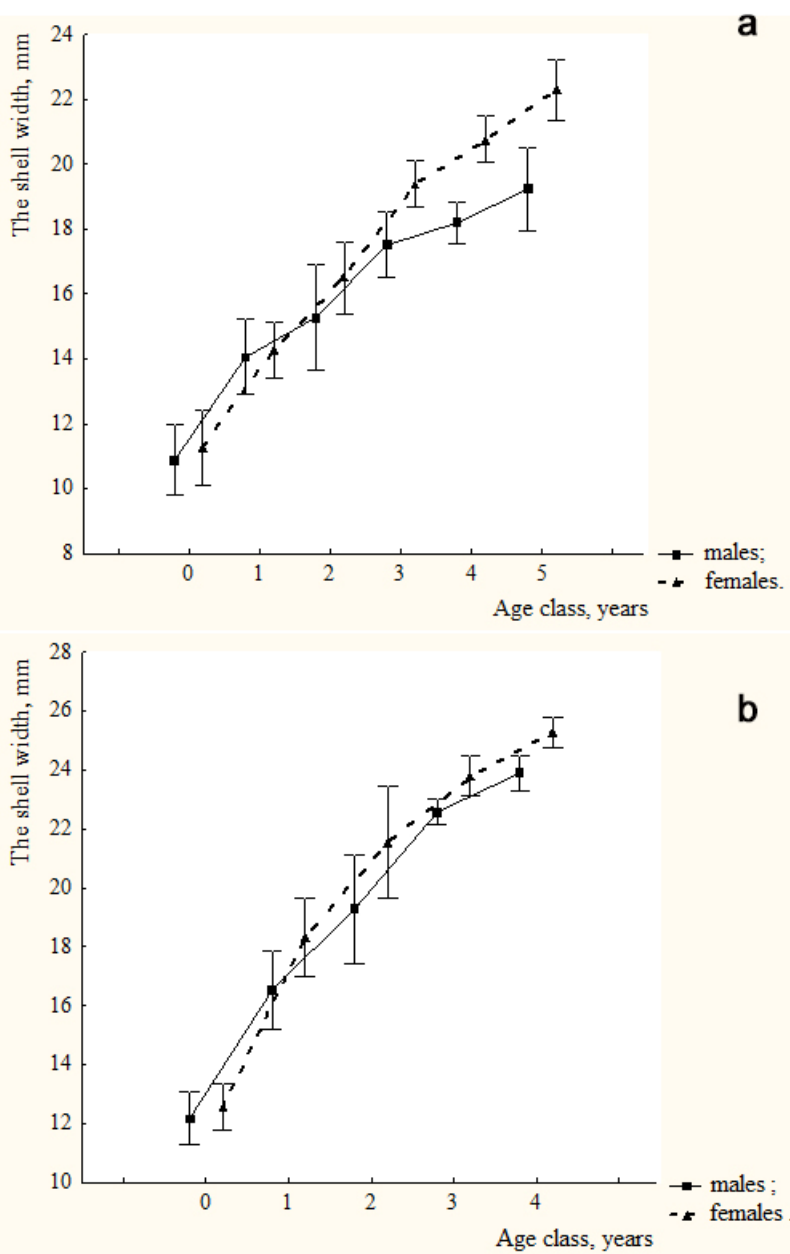

Fig. 5. Relationships of age and shell width in males and females of $V$. viviparus from the Irsha river (city of Khoroshiv, Zhytomyr region) (a), and $V$. contectus from the floodplain of the Tnya river (village of Nesolon, Zhytomyr region) (b) in August 2016.

As for the relative values of the conchological character of $V$. viviparus males and females, starting at the age of 2 years, the most reliable for sex differentiation is the SW/SH index. Only at the age of 3 years, the indices of $\mathrm{BWH} / \mathrm{SH}$ and $\mathrm{AW} / \mathrm{SH}$ are significantly $(p=0.05)$ higher in females compared with males.

During the morphological study of the conchological parameters of $V$. contectus in the population from the floodplain of the Tnya river, only one 5-year-old male was found, and 6 years-old snails were not recorded at all. Therefore, we did not statistically analyze the age class of 5-6 years.

It should be noted that in other populations of $V$. contectus, as well as $V$. viviparus, males of this age are also very rare. The reasons for the number of males decreasing with age in the populations of Viviparus remain unclear. Possibly, one of the causes are trematode infections. After all, higher infection rates are noted for older males than females of the same age. There is an evidences that males are less resistant to parasitism in general and to trematodes in particular [23]. Lower ratio of males in the freshwater snail populations may also be associated with less favourable conditions for their existence in the modernized transformed water bodies of the Ukraine, where females exhibit greater viability. V. A. Geodakyan [24] considers that male individuals of many animals in the populations have less sustainability to influence of unfavorable environment factors. The revealed changes in the sexual structure of the viviparid populations can be considered an adaptive strategy for reproduction in a transformed environment.

No significant sexual differences were noted in the shell height of $V$. contectus snails (Table 2). Shell width from the age of one year, and body whorl height from the age of three years were significantly higher $(p=0.05)$ in females than in males. We also analysed the variability range of shell width for $V$. contectus males and females with different ages (Fig. 5b), and noted that the minimum and maximum values of that character often overlapped in both sexes.

Table 2. Sex differences in shell morphometrics and indices (x $\pm \mathrm{m}_{\mathrm{x}}$ ) of $V$. contectus of different ages collected in August 2016 at the floodplain of the Tnya river (village of Nesolon, Zhytomyr region).

\begin{tabular}{|c|c|c|c|c|c|c|}
\hline \multirow{2}{*}{$\begin{array}{l}\text { Age } \\
\text { class, } \\
\text { years }\end{array}$} & \multirow[b]{2}{*}{$n$} & \multicolumn{5}{|c|}{ Shell morphometrics ${ }^{1}, \mathrm{~mm}$} \\
\hline & & $S H$ & $S W$ & BWH & $A H$ & $A W$ \\
\hline \multirow{2}{*}{$0+$} & 20 & $16.4 \pm 0.1$ & $12.2 \pm 0.1$ & $10.1 \pm 01$ & $10.2 \pm 0.1$ & $8.2 \pm 0.1$ \\
\hline & $\overline{20}$ & $\overline{16.5 \pm 0.1}$ & $\overline{12.6 \pm 0.1}$ & $\overline{10.2 \pm 0.1}$ & $\overline{10.0 \pm 0.1}$ & $\overline{8.3 \pm 0.1}$ \\
\hline \multirow{2}{*}{$1+$} & 20 & $21.1 \pm 0.2$ & $\underline{16.4 \pm 0.1^{*}}$ & $\underline{11.1 \pm 0.2}$ & $12.0 \pm 0.2$ & $\underline{8.9 \pm 0.1}$ \\
\hline & $\frac{-5}{20}$ & $22.2 \pm 0.1$ & $18.1 \pm 0.2$ & $12.8 \pm 0.1$ & $13.1 \pm 0.1$ & $10.0 \pm 0.2$ \\
\hline \multirow{2}{*}{$2+$} & 20 & $25.1 \pm 0.3$ & $19.2 \pm 0.2^{*}$ & $12.7 \pm 0.3$ & $14.0 \pm 0.3$ & $9.5 \pm 0.1$ \\
\hline & $\overline{20}$ & $\overline{24.8 \pm 0.2}$ & $\overline{21.4 \pm 0.2}$ & $\overline{13.5 \pm 0.2}$ & $\overline{14.8 \pm 0.3}$ & $\overline{10.5 \pm 0.1}$ \\
\hline \multirow{2}{*}{$3+$} & $\underline{15}$ & $26.0 \pm 0.4$ & $\underline{22.7 \pm 0.3^{*}}$ & $\underline{13.3 \pm 0.2 *}$ & $14.8 \pm 0.2^{*}$ & $10.9 \pm 0.2 *$ \\
\hline & $\frac{15}{15}$ & $26.9 \pm 0.3$ & $23.6 \pm 0.3$ & $14.7 \pm 0.2$ & $15.7 \pm 0.1$ & $11.6 \pm 0.1$ \\
\hline \multirow{2}{*}{$4+$} & $\underline{5}$ & $29.2 \pm 0.4$ & $24.0 \pm 0.3^{*}$ & $14.1 \pm 0.3^{*}$ & $15.2 \pm 0.3^{*}$ & $12.0 \pm 0.3 *$ \\
\hline & $\overline{5}$ & $30.1 \pm 0.5$ & $25.2 \pm 0.3$ & $16.7 \pm 0.4$ & $\overline{17.4 \pm 0.4}$ & $13.9 \pm 0.2$ \\
\hline \multirow{2}{*}{$5+$} & $\underline{1}$ & $\underline{32.1}$ & $\underline{24.9}$ & $\underline{15.2}$ & 17.2 & $\underline{13.1}$ \\
\hline & 3 & $34.2 \pm 0.3$ & $28.2 \pm 0.4$ & $18.1 \pm 0.4$ & $19.0 \pm 0.3$ & $14.5 \pm 0.4$ \\
\hline \multirow{2}{*}{$6+$} & $=$ & - & - & - & - & - \\
\hline & $\overline{1}$ & $\overline{37.8}$ & $\overline{28.5}$ & $\overline{19.3}$ & $\overline{19.5}$ & $\overline{14.9}$ \\
\hline \multirow{2}{*}{$\begin{array}{l}\text { Age } \\
\text { class, } \\
\text { years }\end{array}$} & \multirow[b]{2}{*}{$n$} & \multicolumn{5}{|c|}{ Shell indices } \\
\hline & & $\mathbf{S W} / \mathbf{S H}$ & $\mathrm{H} / \mathrm{SH}$ & $A H / S H$ & $A W / S H$ & - \\
\hline \multirow{2}{*}{$0+$} & 20 & $\underline{0.75 \pm 0.01}$ & $\underline{0.61 \pm 0.01}$ & $\underline{0.62 \pm 0.01}$ & $0.50 \pm 0.01$ & \\
\hline & $\overline{20}$ & $0.76 \pm 0.01$ & $\overline{0.61 \pm 0.01}$ & $\overline{0.61 \pm 0.01}$ & $\overline{0.50 \pm 0.01}$ & \\
\hline \multirow{2}{*}{$1+$} & $\underline{20}$ & $\underline{0.76 \pm 0.01}$ & $\underline{0.50 \pm 0.01}$ & $\underline{0.57 \pm 0.01}$ & $\underline{0.38 \pm 0.01}$ & \multirow[t]{2}{*}{-} \\
\hline & 20 & $0.81 \pm 0.01$ & $0.58 \pm 0.01$ & $0.59 \pm 0.01$ & $0.45 \pm 0.01$ & \\
\hline \multirow{2}{*}{$2+$} & 20 & $0.75 \pm 0.01^{*}$ & $\underline{0.50 \pm 0.01}$ & $0.55 \pm 0.01$ & $0.40 \pm 0.01$ & \multirow[t]{2}{*}{ 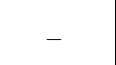 } \\
\hline & $\overline{20}$ & $\overline{0.84 \pm 0.01}$ & $\overline{0.54 \pm 0.01}$ & $\overline{0.56 \pm 0.01}$ & $\overline{0.42 \pm 0.01}$ & \\
\hline \multirow{2}{*}{$3+$} & $\underline{15}$ & $\underline{0.84 \pm 0.01}$ & $\underline{0.50 \pm 0.01}$ & $\underline{0.53 \pm 0.01}$ & $\underline{0.41 \pm 0.01}$ & \\
\hline & $\overline{15}$ & $0.85 \pm 0.01$ & $0.54 \pm 0.01$ & $0.55 \pm 0.01$ & $0.43 \pm 0.01$ & \\
\hline \multirow{2}{*}{$4+$} & $\underline{5}$ & $\underline{0.82 \pm 0.01}$ & $\underline{0.48 \pm 0.01}$ & $\underline{0.51 \pm 0.01}$ & $\underline{0.41 \pm 0.01}$ & \multirow[b]{2}{*}{-} \\
\hline & $\overline{5}$ & $\overline{0.83 \pm 0.01}$ & $\overline{0.53 \pm 0.01}$ & $\overline{0.56 \pm 0.01}$ & $\overline{0.46 \pm 0.01}$ & \\
\hline \multirow{2}{*}{$5+$} & 1 & $\underline{0.80}$ & 0.47 & $\underline{0.53}$ & 0.40 & \multirow[b]{2}{*}{-} \\
\hline & $\frac{1}{3}$ & $0.82 \pm 0.01$ & $0.53 \pm 0.01$ & $0 . \overline{5 \pm 0.01}$ & $0 . \overline{42 \pm 0.01}$ & \\
\hline \multirow{2}{*}{$6+$} & $=$ & - & 二 & - & - & \multirow[b]{2}{*}{-} \\
\hline & $\overline{1}$ & $\overline{0.77}$ & $\overline{0.51}$ & $\overline{0.52}$ & $\overline{0.40}$ & \\
\hline
\end{tabular}

Note: the designations as in Table 1; dash — no data available

In older (3-4-year-olds) females of $V$. contectus, the size (height and width) of aperture is larger than in males. As for the shell indices, a significant $(p=0.01)$ sex difference was found only for SW/SH index in 2-yearolds $V$. contectus.

Correct identification of sex is an important component of wildlife management because changes in sex ratios can affect population viability. Most malacologists, studying sexual morphological 
dimorphism of snails, take into account the absolute and relative indices of the shell and do not consider the age of individuals. For the first time, considering the age of $V$. viviparus and $V$. contectus, the analysis of the conchological parameters of their males and females was performed, and differences in adults were revealed.

Populations of $V$. viviparus from the Irsha river (Khoroshiv, Zhytomyr Region, Ukraine) are similar to populations of this species from other geographical areas - the Dnepr river (Smolensk, Russian Federation) and the Shokhonka river (Ples, Ivanovo region, The Russian Federation) [15].

The revealed pattern of sexual conchological characters in adult snails is noted by malacologists for other members of Caenogastropoda as well. Such a pattern has been found for Melanoides tuberculatus (Müller, 1774) from Israel [25], for Buccinanops globulosus (Kiener, 1834) from Argentina [26].

Differences in the shell morphology of Viviparus males and females are explained by different sizes of mantle section of the male and female reproductive system, located in the body whorl. Pregnant females have a large brood pouch, filled with egg capsules with embryos, which may be quite numerous $[1,27,28]$. The brood pouch is located in the upper part of the mantle cavity and occupies almost the entire volume of the body whorl. The ejaculatory chamber is located in the bottom of the male mantle cavity, and in the inactive state, it occupies a much smaller volume within the body whorl. Other researchers have the same opinion about Viviparidae and other Caenogastropoda [15, 26, 29, 30]. According to results, Viviparidae mollusks can be used as bioindicators in environmental assessment of water bodies. Average shell height of mature ( 2 to 3 year old) snails and sex ratio in populations of Viviparidae are the population characteristics which are the most informative in bioindication with this species (mostly by organic pollutants). Primary sexual structure (age class $0+$ ) of $V$. viviparus expressed as $1: 1$. Reservoirs are characterized by the best conditions for hydrobionts and hydrochemical parameters of water within the limits of norm at equal correlation of mollusks sexes (secondary sexual structure). There is a rejection of this index toward the increase of number of females, rarer - young males in the conditions of environment, less favorable for the organisms. Such reservoirs are characterized by rejections in hydrochemical parameters (concentration oxygen, content of organic matter). Forming of greater amount of females at large anthropogenic influence on reservoirs is adaptive strategy of populations $V$. viviparus in the changing conditions of environment.

\section{Conclusion}

Therefore, the analysis of morphometric conchological characters of the two Viviparus species revealed sexual dimorphism for adult individuals ( $3-5$ years old): females mostly have a wider shell and aperture, and more convex body whorl than males. Differences in the shell morphology of males and females are explained by different sizes of mantle section of the male and female reproductive system, located in the body whorl. However, these parameters often overlap in males and females and do not always permit to identify them reliably. This may be due to the different growth rates of individuals. Hence, we recommend taking into consideration not only the specifics of shells of male and female viviparid snails, but also their head tentacle in the course of bioindication assessments.

\section{References}

1. O. Uvayeva, S. Utevsky, Comparative analysis of population characteristics of two viviparid species (Mollusca, Viviparidae) in water bodies of Ukraine. Biologia, 76(1), 113-122 (2021). doi:10.2478/s11756-020-00504-z

2. V. V. Anistratenko, O. Yu. Anistratenko, Klass Pantsirnye ili KHitony, Klass Bryukhonogie Cyclobranchia, Scutibranchia i Pectinibranchia (chast'). (Class Polyplacophora; Class Gastropoda: Cyclobranchia, Scutibranchia and Pectinibranchia (part)). Fauna of Ukraine 29, Mollusks 1(1), Veles, Kiev (2001)

3. A. Piechocki, B. Wawrzyniak-Wydrowska, Guide to the freshwater and marine mollusca of Poland. Bogucki Wydawnictwo Naukowe, Poznań (2016)

4. E. A. Tsikhon-Lukanina, Trofologiya vodnykh mollyuskov (Trophology of Aquatic Mollusks). (Moscow, Nauka, 1987)

5. E. I. Uvaeva, E. D. Shimkovich, Bioindication significance of population characteristics of viviparids (Mollusca, Gastropoda, Viviparidae) in water bodies of Central Polesia, Ukraine. Uchenye Zapiski Kazanskogo Universiteta. Seriya Estestvennye Nauki, 159(3), 521-530 (2017)

6. T. V. Andriychuk, Minlyvist ta stateva struktura dvokh vydiv kaliuzhnyts Viviparus viviparus (Linnaeus, 1758) i Viviparus contectus (Millet, 1813) (Gastropoda, Viviparidae) u mezhakh Ukrainy: porivnialnyi analiz (The Variability and reproductive organs' structure of Viviparus viviparus (Linnaeus, 1758) and Viviparus contectus (Millet, 1813) (Gastropoda, Viviparidae) within Ukraine: the contrastive analysis). $\mathrm{PhD}$ thesis, Kyiv, 2015

7. T. V. Andriychuk, A. V. Garbar, On sexual dimorphism of karyotypes of Viviparus viviparus and $V$. contectus (Gastropoda, Viviparidae). Vestnik zoologii 49(2), 105-112 (2015). doi:10.1515/vzoo2015-0011

8. Yu. S. Ryabceva, N. V. Vychalkovska, Konkholohichni osoblyvosti cherevonohykh moliuskiv rodu Viviparus v zalezhnosti vid yikh stati (Sex differences in the conchological characters of genus Viviparus). Biology and valeology (19), 79-86 (2018)

9. N. Vychalkovskaya, V. Trofimchuk, Konkholohichni osoblyvosti moliuskiv rodu Viviparus iz richky Pivdennyi Buh ta richky Bucha (Conchometric peculiarities of mollusc's genus Viviparus from 
Southern Buh and Bucha rivers). Naukovyj visnyk of Mykolaiv V.O. Sukhomlynskyi National University. Biological sciences 1(6), 13-18 (2016)

10. A. Falniowski, W. Fialkowski, M. Szarowska, K. Mazan, Shell biometry characters in species discrimination and classification within the genus Viviparus (Gastropoda: Architaenioglossa: Viviparidae). Malakologische Abhandlungen 19, 2945 (1998)

11. M.-Ch. Chang, The anatomy of the fresh water viviparous snails. PekingSoc. Nat. Hist. Bul. 3(4), 45-57 (1929)

12. D. Geyer, Unsere Land und Süsswassermollusken. (Stuttgart, Lutz. XI, 1927)

13. R. L. Minton, L. L. Wang, Evidence of sexual shape dimorphism in Viviparus (Gastropoda: Viviparidae). Journal of Molluscan Studies, 77(3), 315-317 (2011)

14. C. S. O. Moneva, C. G. Demayo, M. A. J. Torres, Applications of geometric morphometric analysis in describing sexual dimorphism in shell shapes in Vivipara angularis Muller (Family Viviparidae). Animal Biology \& Animal Husbandry 4(1), 14-19 (2012)

15. G. V. Berezkina, A. A. Zotin, Razlichiya v morfologii rakoviny samtsov i samok rechnykh zhivorodok Viviparus viviparus (Gastropoda, Viviparidae) (Differences in the morphology of shells in males and females of the river snail Viviparus viviparus (Gastropoda, Viviparidae)). Zoological journal 92(8), 875-882 (2013). doi: 10.7868/S0044513413080047

16. G. V. Berezkina, O polovom dimorfizme v morfologii rakoviny Contectiana contecta (Millet, 1813) (Gastropoda, Viviparidae) (About the sexual dimorphism in the shell morphology of Contectiana contecta (Millet, 1813) (Gastropoda, Viviparidae). Biologicheskie nauki $\mathrm{v}$ shkole $\mathrm{i}$ vuze 15, 18-24 (2014)

17. P. V. Bedova, P. M. Mazurkin, Morfometricheskij analiz rakovin zhivorodki rechnoj Viviparus viviparus (Linne, 1758) vodoemov Respubliki Marij EH (Morphometric analysis of river viviparus's shells Viviparus viviparus (Linne, 1758) of reservoirs in Mari El Republic). PYXIS 4(3), 4-14 (2016)

18. P. V. Kijashko, E. V. Soldatenko, M. V. Vinarski, Klass Bryukhonogie molyuski. Opredelitel' zooplanktona i zoobentosa presnykh vod Evropejskoj Rossii, in: S. Ya. Tsalolikhin (Ed.). A guide to identification of zooplankton and zoobenthos of freshwaters of European Russia). KMK Press, Moscow - St. Petersburg, 2, Zoobenthos, 335-438 (2016)

19. P. Glöer, Sübwassergastropoden. Mollusca I. Nordund Mitteleuropas. (Hackenheim, ConchBooks, 2002)

20. F. W. Welter-Schules, European non-marine molluscs, a guide for species identification. Bestimmungsbuch für europäische Land- und Süsswassermollusken. (Planet Poster Editions, Göttingen, 2012)
21. O. V. Pavliuchenkova, Osobennosti razvitiya polovoj sistemy $\mathrm{V}$ ontogeneze i stanovlenie polovogo dimorfizma u mollyuskov semejstva Viviparidae (Gastropoda Pectinibranchia) (Features of the development of the reproductive system in ontogenesis and formation of sexual dimorphism in mollusks of family Viviparidae (Gastropoda Pectinibranchia)). Scientific Readings in Memory of Professor V. V. Stanchinsky, Smolensk, SSPU 4, 449-453 (2004)

22. G. V. Lakin, Biometriya (Biometrics). (Moscow, Vysshaya Shkola, 1990)

23. K. V. Galaktionov, Zarazhennost' samtsov i samok mollyuskov roda Littorina (Gastropoda, Prosobranchia) partenitami trematod na poberezh'e Barentseva morya (The infection of males and females of molluscs of the genus Littorina (Gastropoda, Prosobranchia) with parthenites of trematodes in the Barents sea coastal waters). Parazitologia 19(3), 213-219 (1985)

24. V.A. Geodakyan, Differentsial'naya smertnost' i norma reaktsii muzhskogo i zhenskogo pola (Differential mortality and reaction norms of males and females). Journal of general biology 35(3), 376-385 (1974)

25. S. Brande, M. Turner, J. Heller, O. Ben-Yehuda, Statistical discrimination of sex in Melanoides tuberculata (Gastropoda: Thiaridae). Biological Journal of the Linnean Society 59(1), 87-112 (1996). doi:10.1111/j.1095-8312.1996.tb01454.x

26. F. Márquez, A. Averbuj, Sexual dimorphism in the shell of a nassariid gastropod. A 3D geometric morphometrics approach. Journal of the Marine Biological Association of the United Kingdom 97(2), 249-255 (2017). doi:10.1017/S0025315416000254

27. B. Jakubik, Life strategies of Viviparidae (Gastropoda; Caenogastropoda; Archtaenioglossa) in various aquatic habitats Viviparus viviparus (Linnaeus, 1758) and V. contectus (Millet, 1813). Folia Malacol. 20(3), 145-179 (2012)

28. T. Samochwalenko, A. Stańczykowska, Fertility differentiation of two species of Viviparidae (Viviparus fasciatus Müll. and Viviparus viviparus L.) in some environments. Ekol. Pol. 20, 479-492 (1972)

29. G. V. Berezkina, Nekotorye voprosy morfologii razmnozheniya presnovodnykh grebnezhabernykh mollyuskov (Gastropoda: Pectinibranchia) Evropejskoj chasti Rossii (Some questions on morphology of reproduction of freshwater Pectinibranchia molluscs (Gastropoda: Pectinibranchia) in the European part of Russia). (Vyd-vo of Smolensk State University, Smolensk, 2011)

30. K. P. Sanchez-Escalona, P. A. Alino, A. JuinioMenez, Evidence of shape sexual dimorphism in Strombus luhuanus Linnaeus 1758 (Gastropoda: Strombidae). Journal of Conchology 42(6), p. 1 (2017) 